\title{
FRAY LUIS DE LEÓN Y TERESA DE JESÚS: ENCUENTROS EN EL LIBRO FRAY LUIS DE LÉON AND TERESA DE JESÚS: ENCOUNTERS IN THE BOOK
}

\author{
JAVIER SAN JOSÉ LERA \\ (Universidad de Salamanca)
}

\begin{abstract}
RESUMEN:
La condición histórico-literaria de los textos teresianos no puede ser estudiada sin tener en cuenta el papel intermediario que, en su configuración, en su transmisión y en su valoración, juega la labor filológica de fray Luis de León. El encuentro en el libro del agustino con la Madre resulta esencial y visibiliza el poder sobre la escritura que se ejerce por parte del teólogo salmanticense, a quien se otorga esa capacidad de control, en función de su autoridad, por parte de las responsables carmelitas. El estatus social y cultural del agustino actúa de aval y es esencial para la institucionalización de los escritos de la madre. Palabras clave: Fray Luis de León, Teresa de Jesús, Edición Salamanca 1588, Legitimación.
\end{abstract}

ABSTRACT:

The literary historical character of the Teresian texts cannot be studied without taking into account the intermediary role that the philological work of Fray Luis de León plays in its configuration, in its transmission and in its evaluation. The encounter in the book of the Augustinian with Teresa is essential and makes visible the power upon writing that is exerted by the Salamanca theologian, based on his prestige, which is recognised by Carmelite authorities. The Augustinian friar social and cultural status acts as a guarantee and it is essential for the institutionalization of the mother's writings.

KEY WORDs: Fray Luis de León, Teresa de Jesús, edition Salamanca, 1588, Legitimacy

Tan pequeño como se siente uno cuando se asoma a esos abismos de honduras de expresión, de sentido y de sentimiento que son los grandes autores de nuestra espiritualidad áurea, resulta comprometido emprender la indagación del espacio histórico-literario en el que se produce el encuentro entre dos de estos grandes entre los grandes: fray Luis de León y Teresa de Jesús. Los elijo por su dimensión creadora, su espacio en la historia literaria y también por su vinculación patrimonial con Castilla * Recibido: 29-07-2020 / Aceptado: 29-09-2020. 
y León; Teresa por su nacimiento en Ávila; fray Luis por elegir a Salamanca como lugar mental de su actividad intelectual. Ambos representan dos caminos de estilo y espiritualidad radicalmente distintos, dos caras de ese poliedro cultural que dibuja la complejidad y el peso de lo religioso en la sociedad española de la segunda mitad del siglo XVI. Si la Madre Teresa escribe desde una cierta «espontaneidad heterodoxa» ${ }^{1}$, fray Luis lo hace desde una ortodoxia retórica rigurosa, precisa y consciente («que es nuevo y camino no usado por los que escriben en esta lengua poner en ella número, levantándola del descaimiento ordinario. El cual camino quise yo abrir...»)2. Azorín, con sagacidad de lector atento, imaginaba a la santa en su «celdita» y caracterizaba el estilo de la santa con otro diminutivo, «limpito», esos diminutivos tan numerosos que ella emplea -«tropiecillos», «ocasioncillas», «espinita», «pequeñita», casos todos ellos de las Meditaciones sobre el Cantar-y su prosa como un hontanar que surge directamente del espíritu, espontáneamente, puro, elemental ${ }^{3}$. En contraste, el mismo Azorín sitúa a fray Luis de León dentro de ese torrente de retórica clásica que comparte con el otro Luis, el de Granada, y señala cierto excesivo peso retórico en su obra, tan alejado de la levedad diminutiva teresiana ${ }^{4}$.

Y si sus caminos estilísticos son tan distintos, lo es también su planteamiento espiritual. Santa Teresa y fray Luis de León ofrecen, también desde esa perspectiva, dos aspectos complementarios de la espiritualidad del siglo XVI. Santa Teresa propone un acercamiento más afectivo al conocimiento de Dios, una vía característica de la mística cristiana, y una espiritualidad focalizada en la instrucción de sus monjas. Fray Luis de León representa la vía intelectual, la del teólogo profesional que escribe tratados, exposiciones bíblicas y dicta cursos teológicos para sus estudiantes universitarios. Lo cual no quiere decir que sean territorios estancos e incomunicados. Muy al contrario: fray Luis aspiraba a esa efusión mística, como muestra, por ejemplo, el arrebato estético y espiritual de la Oda III: « ¡Oh desmayo dichoso! / ¡Oh muerte que das vida! ¡Oh dulce olvido!». Teresa de Jesús era, por su parte, consciente de la necesaria formación y cultivo con la lectura de buenos libros:

\footnotetext{
${ }^{1}$ GARCÍA DE LA Concha, V., El arte literario de Santa Teresa, Barcelona: Ariel, 1978, p. 97. «De "trastornar la retórica" (...) surge una auténtica vocación literaria», GARCíA DE LA CoNCHA, V., «Teresa de Jesús», en Teresa de Jesús. La prueba de mi verdad (Catálogo de la exposición), Madrid, BNE, AC/E, 2015, p 12. La heterodoxia de Teresa deja huella en el audaz ensayo que la dedica Kristeva, J., Teresa. Amor mío, Barcelona, Paso de Barca, 2015 o en la ficción arriesgada de MoRALEs, C. Introducción a Teresa de Jesús, Barcelona, Anagrama, 2020.

${ }^{2}$ Fray Luis de León, De los nombres de Cristo, libro III, Dedicatoria, p. 333.

${ }^{3}$ Azonín, «Teresa de Jesús (1515-1582», Los clásicos redivivos, Madrid, Austral, 1945, pp. 39-43, pp. 39 y 42. MANcho DuQue, Ma J., «Claves de la escritura teresiana», Salamanca. Revista de Estudios 59 (2014), 103-122. Las citas de Santa Teresa proceden, salvo indicación contraria, de Obras completas, Madrid, Aguilar, 1990, $11^{\underline{a}}$ ed.

${ }^{4}$ «Hay algo -mucho- de cansado y prolijo en este libro [De los nombres de Cristo]», Azorín, Los dos luises y otros ensayos, Madrid, Austral, 1944, p. 99.
} 
Tenga cuenta la priora con que haya buenos libros, en especial Cartujanos, Flos Sanctorum, Contemptus Mundi, Oratorio de religiosos, los de fray Luis de Granada, y del Padre Fray Pedro de Alcántara, porque es en parte tan necesario este mantenimiento para el alma, como el comer para el cuerpo (Constituciones, p. 674).

Y cuando no por la lectura de los libros, a través del contacto con los letrados: «Siempre informaos, hijas, de quien tenga letras, que en estas hallaréis el camino de la perfección con discreción y verdad» (Fundaciones, cap. 19, p. 593), porque es consciente de que «La tierra que no es labrada, llevará abrojos y espinas, aunque sea fértil, ansí el entendimiento del hombre» (Avisos de la Madre Teresa de Iesus para sus Monjas, 1, p. 699).

El encuentro de esas dos personalidades aparentemente tan diversas se produjo no en el espacio real, sino en el espacio virtual del libro, esencialmente el que sale a la luz en las prensas salmantinas de Guillermo Foquel en 1588, a los seis años de la muerte de la Santa y contiene la primera edición conjunta de la Vida, Camino de Perfección y Moradas, preparados y prologados por fray Luis con el título Los libros de la Madre Teresa de Jesús, fundadora de los monesterios de monjas y frayles Carmelitas descalços de la primera regla. Fray Luis deja huella de esa circunstancia en la primera frase de la carta dedicatoria con que inicia la edición: "Yo no conocí ni vi a la Madre Teresa de Jesús mientras estuvo en la tierra».

Otro encuentro pudo haber tenido lugar quizá, pero esto es más problemático y no pasa de ser hipotético y necesitado de indagación más minuciosa, en el libro bíblico que inspira a ambos dos obras diversas, un Comentario (fray Luis) y unas Meditaciones (Teresa de Jesús). Me refiero, claro al Cantar de los Cantares, del que la madre Teresa pudo conocer, quizá, una de esas copias manuscritas del comentario en romance, multiplicadas por doquier, que circularon aquí y allá con la problemática obra de fray Luis. Aunque también es posible que el encuentro se produjera en sentido inverso, es decir, que el teólogo salmantino pudiera leer alguna copia de las Meditaciones de la Madre, y que quizá dejara huella en alguno de sus escritos, especialmente en el nombre «Esposo» de De los nombres de Cristo y en la explicación según el sentido espiritual de los Cantares de Salomón, de $1589^{5}$.

En los procesos de beatificación de Teresa la madre María de San José declara que

\footnotetext{
${ }^{5}$ Ver García de la Concha, V. «De los nombres de Cristo, comentario al Cantar de los Cantares», en García de la Concha, V. y San José Lera, J., Fray Luis de León. Historia, humanismo y letras, Salamanca, Ediciones Universidad Salamanca, 1998, pp. 381-394.
} 
el padre fray Luis de León y otras personas doctas fueron de parecer que algunas de ellas se imprimiesen, que son las que están al cabo de la Vida de la dicha Madre, y otras por ser muy subidas de espíritu y no todos las alcanzarán no se imprimieron'.

Entre las que no se imprimieron en la edición de 1588, por prudencia o temor, "por ser muy subidas», seguramente debemos contar las Meditaciones sobre el Cantar; pero es evidente que da a entender que fray Luis las conoció7.

El del libro de Salomón es un espacio querido y compartido por los dos autores; pero un espacio peligroso cuando se trataba de verterlo y explicarlo en romance. Más peligroso aún si provenía de las manos de una mujer. Y más aún si era una mujer indocta, susceptible de engaños y falsas revelaciones, como apuntaron quienes obligaron a Teresa a quemar su obra -el confesor Diego de Yanguas- y quienes denunciaron a la Inquisición primero los escritos de la Madre y luego la edición del propio fray Luis ${ }^{8}$.

Entre otros libros que escribió, era uno de divinos conceptos y altísimos pensamientos del amor de Dios y de la oración y otras virtudes heroicas, en que se declaraban muchas palabras de los Cantares de Salomón, el cual libro (como pareciese a un su confesor cosa nueva y peligrosa que mujer escribiese sobre los Cantares) se le mandó quemar, movido con celo de que, como dice San Pablo, "callen las mujeres en la Iglesia de Dios", como quien dice: no prediquen en púlpitos, ni lean en cátedras, ni impriman libros... y así al punto que este Padre se lo mandó, ella echó el libro en el fuego, ejercitando sus dos heroicas virtudes de la humildad y obediencia (Conceptos de amor de Dios, Bruxelas, 1611, prólogo $)^{9}$.

La construcción del desposorio espiritual entre el Esposo y el alma, la indagación de la doble naturaleza, humana y divina de Cristo son asuntos que aparecen en la reflexión de la mística y en el teólogo. Tendremos que dejar la indagación de este espacio -tan rico y sugerente- de encuentro en el libro bíblico de los dos autores espirituales para otro momento.

Fray Luis -como gato escaldado, que conocía los peligros de esos tiempos reciospudo bien haber sido uno de esos «doctos hostiles» contra la Madre ${ }^{10}$; y sin embargo

\footnotetext{
${ }^{6}$ María de San José, Procesos de beatificación y canonización de Santa Teresa de Jesús, ed. Silverio de Santa Teresa, OCD, Burgos, Monte Carmelo 1934, vol. 2, p. 317.

${ }^{7}$ Las Meditaciones se editaron en 1611 con el título Conceptos del Amor de Dios; ver Márquez Villanueva, F. «La vocación literaria de Santa Teresa», Nueva Revista de Filología Hispánica, 32.2 (1983), p. 367, n. 30, que señala una «curiosa armonía preestablecida entre las ideas bíblicas de fray Luis y de santa Teresa».

${ }^{8}$ Todo el proceso fue estudiado y editado por LLAmAs MARTínEz, E., OCD. Santa Teresa de Jesús y la Inquisición española, Madrid, CSIC, 1972.

${ }^{9}$ Cit. en MARoto, Daniel de Pablo, «Meditaciones sobre los Cantares», en Alberto Barrientos, dir., Introducción a la obra de santa Teresa, Madrid, Editorial de Espiritualidad, 1978, p. 385.

${ }^{10}$ MenÉndez PidAL, R. «El estilo de Santa Teresa», La lengua de Cristóbal Colón, Madrid, Austral, 1978, 6ae ed., p. 121. Los contextos de recepción hostil de escritos de autoría femenina y sus consecuencias en los procesos de legitimación autorial se estudian con acierto por BARANDA, N. «Nombres aniquilados: publicaciones femeninas y lectores», Criticón, 125 (2015), pp. 65-77.
} 
tuvo el valor de asumir el riesgo, y la capacidad y la lucidez de saber apreciar (es decir, dar precio y valor) la novedad y la fuerza de un estilo fuera de toda norma y del provecho espiritual que se podía seguir de la lectura de esas obras singulares. Y el valor de salir en defensa ideológica de las comprometidas vivencias de la Madre, y de sus hermanas, que reavivaron en él, sin duda, un nuevo interés en la espiritualidad mística y en la vida contemplativa ${ }^{11}$.

Ofrece interés a este respecto la carta relación que fray Diego de Yepes, obispo de Tarazona, dirige a fray Luis de León. La carta relación deja huella de los primeros pasos para la realización de la edición de 1588, que se inician con el encargo del Consejo Real para examinar el libro de la Vida:

Estando yo en S. Hieronimo de Madrid y Vuestra Paternidad en su Monasterio de S. Phelippe, aviendo comunicado cosas de la s. Madre Teresa de Jesús (al tiempo que el Consejo Real encomendó a Vuestra Paternidad examinasse el libro que ella dexó escrito de su vida, pareciéndole que algunas que yo le refería eran notables y que no estaban en él, mandó se las enviasse por escrito, para que si pareciesse convenir, se pusiessen en sus propios lugares en la Historia que de su vida y otras se tratara de imprimir. Yo holgué infinito de ver puesto este thesoro al examen de V.P., de quien presumo que entro todos los que le podían mirar sobra [sic por sabrá] penetrar sus riquezas, calificarlas y autorizarlas $^{12}$.

La situación a que apunta fray Diego nos remite unas fechas que van de diciembre de 1584 a julio 1585, cuando fray Luis pasa una temporada en Madrid por asuntos de la Universidad; aunque vuelve a la capital más tarde, en noviembre del 86 y en septiembre del 87, cuando firma ya en el convento agustino de San Felipe la censura y aprobación de las Obras de Teresa de Jesús. Lógicamente ese examen del que trató con fray Diego debió ser previo a la edición. En 1586 el manuscrito del libro de la Vida sigue en manos de la Inquisición, y la madre Ana de Jesús, con el acuerdo del Cardenal Gaspar de Quiroga, a la sazón Inquisidor General, llevó el manuscrito a las autorizadas manos de fray Luis, que estaba entonces en Madrid ${ }^{13}$. No debe olvidarse

\footnotetext{
${ }^{11}$ La defensa llevada a cabo por fray Luis de la Orden carmelitana puede verse en LLAMAS, ob. cit., y resumida en ViÑAS, T., Fray Luis de León. El hombre, el teólogo, el poeta, el amigo, el místico, Salamanca, Diputación de Salamanca, 2018, pp. 193-200. Para todo el intercambio espiritual entre fray Luis y santa Teresa, con detallada reconstrucción histórica del proceso editorial del agustino debe verse ahora LAZCANo, R., «Fray Luis de León, editor y biógrafo de Teresa de Jesús (1515-1582)», Analecta Augustiniana 78 (2015), pp. 78 115.».

${ }^{12}$ YePES, D., Breve relación de algunas cosas notables de la santa madre Teresa de Jesús, escrita y enviada por el Reverendíssimo Obispo de Tarazona, Fray Diego de Yepes, siendo visitador de su Orden, al doctíssimo Padre Fray Luis de León Catedrático de Escritura de la Universidad de Salamanca. La carta se imprime por primera vez en la edición de las obras de Santa Teresa, en Nápoles, por Constantino Vidal, 1604, sin paginación, de donde transcribo; existe copia manuscrita en el Ms 12763 de la BNE, ff. 295-314.
}

${ }^{13}$ A la altura de 1584, cuando Juan de la Cruz está escribiendo su comentario al Cántico 13, 7 «iApártalos, Amado, / que voy de vuelo!» escribe: «Lugar era este conveniente para tratar las diferencias de raptos y éxtasis y otros arrobamientos y sutiles vuelos de espíritu (...) y porque también la bienaventurada Teresa de Jesús, nuestra madre, dejó escritas de estas cosas de espíritu admirablemente, las cuales espero en Dios 
que a Gaspar de Quiroga había dedicado fray Luis de León su primera obra publicada en 1580, In Psalmum XXVI; su condición de «rerum fidei supremo iudice», como le trata fray Luis en esa dedicatoria, y su simpatía por la labor reformadora de Teresa de Jesús debieron influir también para facilitar el proceso de edición de sus obras y para la elección del editor.

En esos mismos años, otro catedrático salmantino, del Colegio de la Compañía de Jesús de Salamanca, el P. Francisco de Ribera pelea con su Orden para obtener licencia de publicación de una Vida de la Madre que ha escrito, y que sale a la luz finalmente en 1590, después de un tenso rifirrafe contra la opinión del General de la Orden, Claudio Aquaviva, que preferiría que fuese otro fraile, mejor carmelita, el que asumiera el riesgo de dar a la luz esas experiencias comprometedoras, porque «juzgan por cosa de mucho inconveniente estamparle en nombre de ninguno de la Compañía (...) por tener algunas revelaciones que no son para todos» ${ }^{14}$. También el dominico fray Domingo Báñez, en la censura que emite para la Inquisición sobre el Libro de la Vida apunta al mismo asunto, ya en 1575: «Solo una cosa hay en este libro en que poder reparar, y con razón; (...) y es que tiene muchas revelaciones y visiones», aunque acaba reconociendo la virtud y cristiandad que acompañan a las de la Madre ${ }^{15}$.

Estas reticencias que se expresan desde importantes ámbitos de la espiritualidad áurea, ponen en valor el de fray Luis de León al asumir la encomienda de las madres carmelitas para editar las obras de la Madre e insistir precisamente en ese punto de la polémica:

«Cuéntanse en estos libros revelaciones...y habrá por ventura quien diga, en las revelaciones, que es caso dudoso, y que así no convenía que saliesen a luz... en que verdaderamente no tienen razón... Y así, ninguno que bien juzgue tendrá por bueno que estas revelaciones se encubran $»^{16}$

porque las revelaciones santas merecen ser sabidas y escritas, dice. Son consecuencias de esos «tiempos recios» que con tanta justeza identificaba Teresa de Jesús al relatar sus propias experiencias:

saldrán presto impresas a luz...»; esto indica que tiene noticia -quizá a través de Ana de Jesús- en esa fecha de los intentos de edición por parte de las carmelitas. Ver Sebastián MEdiavilLa F. «Historia del texto», en Teresa de Jesús, Libro de la vida, ed. cit., p. 480.

Los avatares inquisitoriales del manuscrito del Libro de la Vida pueden seguirse en LLAMAS, ob. cit., pp. 227-277 desde su nacimiento «bajo un signo inquisitorial» (el de la obediencia) hasta su estampación en la edición preparada por fray Luis; la intervención de la madre Ana de Jesús puede leerse en la p. 287.

${ }^{14}$ Carta de Aquaviva a Ribera 21 de marzo de 1589, en Lopetegui, L., «Censura de la Orden de la Vida de Santa Teresa de Jesús, por Francisco de Ribera, S.I.», Manresa vol. 16, oㅡ 60 (1944), p. 270.

${ }^{15}$ Aprobación que el maestro fray Domingo Báñez dio del espíritu de santa Teresa y de la relación autobiográfica de su Vida, en TERESA De Jesús, Libro de la vida, ed. Fidel Sebastián, Madrid, Real Academia Española, 2014, p. 381. Sobre esta censura de Báñez y el papel del dominico véase LlAMAS, ob. cit., pp. 261-262.

${ }^{16}$ Teresa DE Jesús, Los libros... ed. cit.,1588, pp. 12-13. 
También comenzó aquí el demonio, de una persona en otra, procurar se entendiese que había yo visto alguna revelación en este negocio, e iban a mí con mucho miedo a decirme que andaban los tiempos recios, y que podría ser me levantasen algo y fuesen a los inquisidores ${ }^{17}$.

La frase "Yo no conocí ni vi a la Madre», a la que me referiré más adelante, es la primera de la Carta dedicatoria de fray Luis de León en la primera edición mencionada; esta frase no es casual: responde a una realidad (nunca se produjo el encuentro entre ambos). A pesar de lo cual hubo varias posibilidades de coincidencia de ambos, fray Luis y Teresa en el espacio físico de Salamanca.

Teresa llega a Salamanca desde Ávila el 31 de octubre de 1570, víspera de Todos los Santos, para fundar convento. A la altura de 1570 fray Luis de León es Catedrático de Durando, cátedra cursatoria, es decir, no en propiedad, de la Facultad de Teología. En 1569 se inicia en la Universidad la comisión de teólogos presidida por el decano Francisco Sancho para examinar el texto de la Biblia de Vatablo y su posible reimpresión por el librero salmantino Portonaris. En ese contexto tienen lugar los enfrentamientos de fray Luis con el dominico León de Castro, que son la chispa que encenderá la mecha de las acusaciones, alimentadas durante años por rencillas y peleas en torno a las cátedras universitarias («que todos vivíamos como en guerra por razón de las pretensiones y competencias», declara fray Luis en el proceso). Durante el curso 1569-1570 la Universidad le encarga a fray Luis que viaje a Madrid para defender un aumento de salario de las cátedras menores. El 11 de febrero de 1570 parte para Madrid y no volvería a Salamanca hasta finales septiembre, para iniciar en octubre inicia el curso 1570-1571. La Madre había llegado el 31 de octubre.

A Salamanca vuelve la Madre Teresa en 1573 para culminar la compra de la nueva casa para su convento, y permanece en la ciudad hasta enero de 1574 (luego está en Alba). Pero fray Luis está ya preso en Valladolid (donde por cierto está la santa en los finales de 1574 y principios de 1575, es decir, coincidieron de nuevo en el espacio, pero sin posibilidad de encuentro). Para Teresa el caso del procesamiento de fray Luis y de otros profesores del estudio salmanticense debió revivir el recuerdo de aquellos «tiempos recios» que rodearon el proceso del arzobispo Carranza en 1559; sin duda lo conoció, porque fue suceso relevante, pero nunca se refirió a él por escrito.

En octubre de 1579 Teresa está de otra vez en Salamanca por nuevos problemas con las casas para la comunidad (escasas en la ciudad y caras... Teresa se queja del mal trato de los caballeros propietarios de Salamanca, como sabemos por el epistolario) ${ }^{18}$.

\footnotetext{
${ }^{17}$ Teresa DE Jesús, Libro de la vida, 33, ed. cit., pp. 257-258.

${ }^{18}$ Las cartas de Teresa de Jesús son un arsenal de informaciones respecto a su mundo cercano y sus sentimientos, como muestra EGIDo, T., «Santa Teresa y sus cartas, historia de los sentimientos», Hispania
} 
Apenas está en la ciudad un par de meses. En ese tiempo fray Luis inicia el curso como catedrático de Filosofía Moral, pero apenas imparte cinco lecciones, que interrumpe para preparar la oposición a la Cátedra de Biblia, que ganará en diciembre, esa ya en propiedad, culminando entonces su cursus honorum académico. Tampoco entonces se produjo el encuentro entre ambos.

Teresa ha tratado en Salamanca, sobre todo, con jesuitas y dominicos, dos de los cuales, Domingo Báñez y Bartolomé de Medina, catedráticos de Teología, y confesores de la madre en momentos distintos, son protagonistas principales del proceso contra fray Luis.

Así pues, el encuentro personal nunca se produjo; y el otro, tardará todavía unos años en producirse, tras la muerte en olor de santidad (y veremos que esto es literal) de la Madre Teresa de Jesús en el convento de Alba de Tormes. Ese encuentro se produce, como ya he dicho, en el terreno del libro, dando lugar a la preparación de la primera edición de las obras de la Madre: Los libros de la Madre Teresa de Jesús, fundadora de los monesterios de monjas y frayles Carmelitas descalços de la primera regla. En Salamanca. Por Guillelmo Foquel, 1588.

La frase «Yo no conocí ni vi a la madre...» con que se abre esa edición, parece respuesta a la carta relación de Diego de Yepes, ya citada, que había escrito: «Yo tengo por singular merced de Nuestro Señor, y medio muy eficaz de mi salvación, el averla tratado (...) Y assí fue como milagro el motivo que tuve para conocerla» (cursivas mías). Pero, además, la frase inicial de fray Luis «Yo no conocí ni vi...» responde también a la voluntad de dialogar con la carta dedicatoria que abre el único libro editado de la Madre Teresa antes del de fray Luis: la edición que del Camino de Perfección había salido en Évora en 1583 y de nuevo en Salamanca en 1585, en las mismas prensas de Guillelmo Foquel en que saldrá la recopilación de fray Luis. En esa edición, el Obispo de Évora Teotonio de Braganza, comienza su carta dedicatoria así:

Entre las mercedes que de nuestro Señor tengo recebidas, no es la menor, aver me dado familiar conocimiento de la muy reverenda madre Teresa de Iesus, que es en gloria: porque en ella vi resplandecer los dones de nuestro Señor y de su divina gracia (cursiva mía) ${ }^{19}$.

De hecho, la frase de fray Luis contradice un tópico prologal de la literatura femenina, que se presenta por parte de un fraile que había conocido a la mujer y que

Sacra LXVII,136, (2015), pp. 401-428. Es necesario ahora para este territorio recurrir a la tesis doctoral de GARriga Espino, A. Teresa de Jesús en el laberinto de sus cartas, Madrid, UAM, 2017.

19 «Theotonio de Bargança [sic] indigno arçobispo de Evora en Portugal a las muy religiosas y devotas madres de los monesterios de la primera regla de nuestra señora del Carmen, salud en Iesu Christo nro. Señor», en TERESA DE JEsús, Tratado que escrivio la madre Teresa de Jesus a las hermanas religiosas dela orden de nuestra senhora del Carmen del monesterio del senhor sanct Joseph de Avila de donde a la sazon era priora y fundadora, Évora, viuda de Andrés Burgos, 1583. 
se expresa como testigo desde la admiración ${ }^{20}$. Frente al «familiar conocimiento» y el testimonio personal («en ella vi...»), fray Luis solamente puede argumentar su capacidad de lector y estudioso, que esgrimirá con orgullo, porque sobre esas cualidades construye su edición.

Son conocidas las circunstancias en que se lleva a cabo la edición de las obras de la Madre ${ }^{21}$ : el consejo supremo del Carmelo teresiano decide editar las obras de la madre fundadora (1 septiembre 1586) y le encarga a la Madre Ana de Jesús, sucesora de Teresa de Jesús al frente de la reforma carmelitana, que rescate de la Inquisición el autógrafo del Libro de la Vida. Ana de Jesús (digna sucesora de la fundadora, fundadora ella misma en Francia y Bélgica) está por entonces en la Corte, al frente del convento de Madrid; allí coincide con fray Luis que ha ido, una vez más, a ocuparse de asuntos universitarios (un pleito con el colegio del Arzobispo Fonseca) y permanecerá entre noviembre de 1586 hasta octubre de 1589. A finales de 1586 se produjeron, seguramente, los primeros contactos entre fray Luis y la monja carmelita, según señala el P. Manuel Vidal:

...Le fio el real Consejo la corrección de las obras de la Seráphica Virgen Santa Teresa depravadas en parte por el descuido y acaso atrevimiento de algunos amanuenses imperitos. Este decreto del Real Consejo fue muy grato a la ilustre sagrada reforma del Carmelo, y especialmente a la venerable y Religiosísimo Convento de Santa Ana de Madrid, que le habían solicitado con vivas ansias. Y este mismo le puso al venerable Padre en precisión de tratar muchas veces con aquella prudente virgen, fiel hija y compañera de la Seráfica madre y heredera en buena parte de su gallardo espíritu, la Venerable Madre Ana de Jesús. Qué mujer fuese esta, de cuán superiores talentos, de cuán seguro y elevado espíritu no hay para qué lo diga yo. Lea quien quisiere saberlo la Vida que de esta gran matrona escribió el Ilmo. Sr. D. fray Ángel Manrique, honra de la Universidad de Salamanca ${ }^{22}$.

Allí mismo cita una carta de la Madre Ana de Jesús a una de sus monjas en la que le pide que trate bien a fray Luis y le tenga en sus oraciones

que se lo debemos todas. Yo más que a persona otra en la tierra. Presto irá a esa. Trátele V.R. que es muy santo, y para cuanto nosotras tenemos menester, tiene mucho caudal de Dios con grande deseo de servir a su Majestad en hacernos bien. Harto nos ha hecho aquí, de que gozará toda la Orden ${ }^{23}$.

\footnotetext{
${ }^{20}$ El carácter de esta estrategia como modelo editorial de la literatura escrita por mujeres ha sido señalado con perspicacia por BARANDA, N., ob. cit., p. 71, y lo encuentra repetido en ediciones como el Libro de la bienaventurada Santa Ángela de Foligno (Toledo 1510), la Obra de las epístolas y oraciones de Catalina de Siena (Alcalá 1512) o el Libro de Oración de Sor María de Santo Domingo (Zaragoza 1518).

${ }^{21}$ Pueden verse relatadas por Jerónimo de San José Historia del Carmen descalzo, Madrid, 1637, p 536, que cita Mancho Duque, Má. J. y Prieto, J.M., eds. Fray Luis de León, De la vida, muerte, virtudes y mlagros de la Santa Madre Teresa de Jesús, Salamanca, Ediciones Universidad, 1991, p. 21. Ver también LazCANo, R., ob. cit.

${ }^{22}$ VIDAL, M. Augustinos de Salamanca. Historia del observantíssimo Convento de S. Agustín N. P. de dicha ciudad, Salamanca, Salamanca, Eugenio García de Honorato y San Miguel, impresor, 1751-58, 2 vols, p. 378a.

${ }^{23}$ Sobre el papel de Ana de Jesús en la edición de las obras de Santa Teresa debe verse, SANTA ANA, B-I., Vida
} 
La relación con Ana de Jesús continúa después de cumplido el encargo, y fray Luis le dedicará su última obra, la más compleja y rica de su producción: La exposición del libro de Job, terminada por fray Luis en 1591, unos meses antes de su muerte y que permaneció inédita hasta 1779. Allí leemos la dedicatoria de «El Maestro frai Luis de León en el Libro de Job a la muy religiosa Madre Ana de Jesús, carmelita descalça»:

sant Pablo dize en su persona: "ya nos gozamos en las tribulaciones". Destos es Vuestra Reverencia y las demás de su orden, que descansan quando padeçen, por mostrar lo que aman. Que el amor de Christo que arde en sus almas, mostrándose descansa y padeciendo se muestra. Y ansí padeçen con gozo, y si no [fol 1v] padeçen, tienen hambre de padecer, que la descubren siempre que pueden y en todo lo que pueden.

Y della nace agora mandarme Vuestra Reverencia le declare el libro de los sucesos y razonamientos de Job. Que como los valientes soldados gustan de conocer los hechos hazañosos de los que fueron, ansí Vuestra Reverencia, en esta milicia de paciencia que profesa, desea reconocer este exemplo excelente ${ }^{24}$.

Es curiosa y significativa esta valoración, porque muestra que la lectura de las obras de la Madre no ha pasado en balde para fray Luis y que su encuentro en el libro ha dado frutos. En efecto, en el Libro de las Fundaciones 28, 43 (y en tantos otros lugares) ha podido leer la valoración de Teresa sobre sus hermanas:

Gran cosa puede la santidad y virtud. Verdad es que eran tales que, aunque hallaran muchas dificultades y trabajos, lo llevaran bien con el favor del Señor, porque desean padecer en su servicio; y la hermana que no sintiere en sí este deseo, no se tenga por verdadera descalza, pues no han de ser nuestros deseos descansar, sino padecer, por imitar en algo a nuestro verdadero Esposo (cursiva mía) ${ }^{25}$.

La lectura de las obras de Teresa de Jesús ha permitido a fray Luis comprobar en ellas una aplicación extensa de la doctrina de la mortificación: no es casualidad que la filosofía y la elaboración metafórica del Libro de Job aparezca con frecuencia en la obra de Santa Teresa. La propia Ana de Jesús, en sus cartas insiste una y otra vez en la idea de la tribulación como fuente de bienes espirituales: «el bien que está escondido en las tribulaciones siempre es mayor del que pueda imaginarse. Por gozar le querría padescer; que tantico que probé me dejó engolosinada ${ }^{26}$. Y fray Luis lo destaca también su Carta dedicatoria: «Porque la mortificación les es regocijo, y la resignación juego, y pasatiempo la aspereza de la penitencia».

de la madre Ana de Jesús, Burgos, Imprenta de San José, 1901, cap. IV, pp. 319-335.

${ }^{24}$ LEón, Fr. L., Exposición del Libro de Job, ed. Javier San José Lera, Salamanca, Ediciones Universidad Salamanca, 1992, p. 144.

25 TERESA DE Jesús, Obras, ed.cit., p. 644.

${ }^{26}$ Carta al P. Diego de Guevara, citada en MAnRIQue, Ángel, Vida de la Venerable Madre Ana de Jesús, Bruxellas, En casa de Lucas de Meerbeck, 1632, p. 326. 
La relación de la Madre Ana de Jesús con los agustinos continúa después de muerto fray Luis, tomando ella sobre sus hombros la responsabilidad de sacar a la luz (infructuosamente, a pesar de su empeño y haber recaudado los fondos precisos) el manuscrito de la Exposición del libro de Job; y recuerda con agradecimiento y cariño la figura del agustino, como cuando escribe ya en 1610 desde Bruselas a fray Diego de Guevara prior en Salamanca, y le manda recuerdos para el sobrino de fray Luis, Basilio Ponce de León. «suplico a Vuestra Paternidad siempre le haga amistad, que todos se lo debemos a su tío, que esté en gloria». Y en 1616 manda de nuevo saludos para fray Basilio «que en el alma tengo siempre a su tío» ${ }^{27}$. Pero esta es otra historia.

El resultado del encargo de la Madre Ana de Jesús y del Consejo Real es el volumen publicado en 1588 en la misma imprenta salmantina en la que, el año antes, 1587, fray Luis ha dado a las prensas su última edición, corregida y aumentada de su obra cumbre hasta ese momento, De los nombres de Cristo. Es la imprenta de Guillermo Foquel, que trabaja en Salamanca (y luego en Madrid) como empleado de Julio Junti² en ella saldrá también la segunda edición de la obra teresiana, en 1589 (por el medio, una edición con algunas irregularidades — sin privilegio, aunque con licencias, con fecha de 1588, pero en realidad de 1589- en Barcelona a cargo de Jayme Cendrat), con algunas interesantes glosas de fray Luis ${ }^{29}$. En la imprenta de Foquel también había salido en 1585 una edición del Camino de Perfección, que es reedición de la primera de esta obra salida en Évora en 1583, a la que ya me he referido ${ }^{30}$. Esa edición teresiana de 1585 se imprime en formato $8^{\circ}$; la de fray Luis sale en $4^{\circ}$. Este detalle material muestra una modificación del espacio de lectura que se contempla para el libro: de la reflexión espiritual individual (el libro que se lleva en la mano, o en la faltriquera y se imprime en octavo) propio de la lectura devota, al libro de formato mayor con contenidos de mayor peso y otro tipo de lectura, para la profundización interpretativa, a la que acompañan y ayudan todo tipo de paratextos ${ }^{31}$.

\footnotetext{
${ }^{27}$ ToRres, C., ed. Ana de Jesús. Cartas (1590-1621). Religiosidad y vida cotidiana en la clausura femenina del Siglo de Oro, Salamanca, Ediciones Universidad, 1995.

${ }^{28}$ ZozAYA MonTes, L., «Algunas aclaraciones sobre Guillermo Foquel, un impresor del siglo XVI», Torre de los Lujanes 43, (2001), pp. 189-203.

${ }^{29}$ ÁLVAREZ, T., «Fray Luis de León y Santa Teresa. El profesor salmantino ante la monja escritora», en Santa Teresa y la literatura mística hispánica, Madrid, ED-6, 1984, pp. 493-502; reeditado en ÁLVAREz TuRIENZo, Saturnino, Escritos sobre Fray Luis de León: el teólogo y maestro de espiritualidad, Salamanca, Ediciones de la Diputación de Salamanca, 1993, pp. 493-502. Del mismo autor, «Santa Teresa de Jesús. Primera onda difusora de sus escritos», en Teresa de Jesús. La prueba de mi verdad (Catálogo de la exposición), Madrid, BNE, AC/E, 2015, pp. 156-158.

${ }^{30}$ Teresa DE JEsús, Tratado llamado Camino de perfeccion / que escrivio para sus Monjas la madre Teresa de Iesus. En Salamanca, en casa de Guillermo Foquel, 1585.

${ }^{31}$ NaKLADÁLová, Y., La lectura docta en la primera Edad Moderna (1450-1650), Madrid, Abada Editores, 213, p. 115 y ss.
} 
La edición de 1588 fija para la posteridad uno de los modelos iconográficos de la Santa Madre, sobre el famoso retrato pintado por fray Juan de la Miseria en Sevilla en 1576, la vera effigies de Teresa (y que a la Madre le gustó poco) ${ }^{32}$. Los preliminares legales, censura y aprobación, adelantan, junto con los tópicos esperables (la sana doctrina y utilidad de la obra, según el precepto horaciano de mezclar utile et dulci: «... que son de muy sana y católica doctrina, y a mi parecer de grandísima utilidad...») una apreciación que desarrolla en la pieza preliminar posterior (la dedicatoria): "Y todo ello con tanta facilidad y dulzura por una parte, y por otra con palabras tan vivas, que ninguno los leerá que si es espiritual no halle grande provecho, y si no lo es, no desee serlo y se anime para ello».

Las «palabras vivas» formalizan en un sintagma de fuerza expresiva la valoración estilística y moral sobre la que inicia el segundo de los textos a los que es necesario volver los ojos: La Carta dedicatoria a las Madres priora Ana de Jesús y religiosas carmelitas descalzas del monasterio de Madrid ${ }^{33}$.

Si la censura era un preliminar legal, la dedicatoria era un preliminar protocolario en el que los autores rendían tributo al mecenazgo, a la amistad y al tiempo buscaban, con frecuencia, protección o beneficio entre los poderosos. Sin embargo, la Dedicatoria de fray Luis va en este caso por otros derroteros, convirtiéndose este texto dedicatorio en la piedra angular del encuentro del teólogo y profesor con la personalidad de la Madre plasmada en sus escritos. Es muy llamativo que ese gran constructor de la sensibilidad lectora de los clásicos en la España moderna que fue Azorín, reclamara la guía de fray Luis para asomarse a la ventana de Santa Teresa: «No se olvide como guía indispensable en el lenguaje teresiano, leer, releer, meditar, comentar las ocho o diez páginas que fray Luis de León dedica a prologar las obras de la santa» ${ }^{34}$. Y a pesar de su brevedad, el texto se ha valorado con toda justicia, entre las mejores páginas de fray Luis $^{35}$.

\footnotetext{
${ }^{32}$ Sobre la vera effigies teresiana y su distribución en copias de óleos y grabados antes de la edición de 1588 trata Pinilla MARTíN, Ma J., «Tipos y temas en la iconografía teresiana, Aspectos relativos a su configuración y desarrollo», pp. 17-30, en Jesús García Rojo, ed., Teresa de Jesús: V centenario de su nacimiento. Historia, literatura y pensamiento, Salamanca, Diputación de Salamanca, 2015, pp. 18-19. CHECA, F., «Santa Teresa de Jesús y las imágenes artísticas», en Teresa de Jesús. La prueba de mi verdad (Catálogo de la exposición), Madrid, BNE, AC/E, 2015, p. 118.

${ }^{33}$ Las citas de este texto clave remiten a la primera edición de Los Libros de la Madre Teresa de Jesús, ed. cit., Salamanca, 1588. La carta, firmada en San Felipe de Madrid el 15 de septiembre de 1587, ocupa las páginas 1-24 (cuadernos A - $\mathrm{B}_{4 \mathrm{v}^{\mathrm{o}}}$ del impreso).

${ }^{34}$ Azorín, «Ventana a Santa Teresa», Revista de Espiritualidad, 87-89 (1963), p. 404.

35 «Merece compararse con las mejores páginas de los Nombres», dice Colin Thompson, que analiza la textura retórica de la pieza en Thompson, C., «"Una elegancia desafeitada”. Fray Luis de León y Santa Teresa», en M.M. Gaylord and F. Márquez Villanueva, eds., San Juan de la Cruz and Fray Luis de León, Juan de la Cuesta, Newark, Delaware, 1996, pp. 289-298, p. 290.
} 
La Carta dedicatoria nos pone en contacto con el fray Luis que lee profesionalmente como filólogo y como teólogo, es decir, con la intención de editar unos manuscritos ${ }^{36}$, de valorar su mérito literario y de ponderar su doctrina teológica. Como crítico textual, como humanista de múltiples lecturas y como teólogo debe actuar, con competencia profesional y con la prudencia que recomiendan los «tiempos recios» en que vive la espiritualidad y las malas experiencias pasadas; por eso anota y revisa y puntualiza pasajes conflictivos, mostrando con valor su «resistencia a la teología oficial $»^{37}$.

Lo primero que leemos en esa carta es una hermosa paradoja, balanceada en parejas, tan del gusto del estilo luisiano ${ }^{38}$ (conocí/vi; estuvo/vive; conozco y veo, tierra/cielo; hijas/libros) sobre la que se construye el propósito retórico inicial de la captatio, publicum attentum parare:

Yo no conocí ni vi a la Madre Teresa de Jesús mientras estuvo en la tierra; mas agora que vive en el cielo la conozco y veo casi siempre en dos imágenes vivas que nos dejó de sí, que son sus hijas y sus libros.

Y los libros de la santa son, entonces, libro vivo, como el que el Señor le dio a esa gran lectora que era Teresa: «Cuando me quitaron muchos libros de romance que no leyese, yo sentí mucho, porque algunos me daba recreación leerlos y yo no podía ya, por dejarlos en latín; me dijo el Señor: "No tengas pena, que Yo te daré libro vivo" ${ }^{39}$. Es relevante que aquí fray Luis le da la vuelta a la metáfora clásica (y desgastada) del libro de la naturaleza o el hombre como libro. Para fray Luis no es que el hombre pueda leerse como si fuera un libro, interpretando su naturaleza humana, sus actos... No, el libro es el hombre: en el libro se lee al hombre, concediendo así una importancia esencial a la lectura. Los libros son un espejo de la persona; incluso reproducen una imagen más sólida, porque son también testigos de la virtud, entendida por fray Luis en su sentido etimológico, como la cualidad de excelencia del vir, sin que tenga el término marca de género: verdad, valor, madurez humana, excelencia de carácter y de mente, mérito moral, sin el que no existe la felicidad: «Y todo su estudio es (...) adelantarse en la virtud de continuo» ${ }^{40}$.

\footnotetext{
${ }^{36}$ Sobre los autógrafos y las copias que pudo manejar fray Luis, véase LAZCANo, R., ob. cit., pp. 84 (Vida), 88 (Camino de perfección), 90 (Moradas y Escritos menores).

${ }^{37}$ ÁLVAREZ, ob. cit., 1984, p. 499.

${ }^{38}$ SAN José LERA, J. «Un recurso clásico en la prosa de fray Luis de León: las parejas de sinónimos en la Exposición del libro de Job», en Manuel García Martín, ed., Estado actual de los estudios sobre el Siglo de Oro: actas del II Congreso Internacional de Hispanistas del Siglo de Oro Salamanca, Ediciones Universidad Salamanca, 1993, Vol. 2, pp. 913-922.

${ }^{39}$ Libro de la vida, 26, 5, ed. cit., pp. 192-193.

${ }^{40}$ La idea procede de Séneca que escribe en De Beneficiis (4.2.3.): ego sine virtute nego beatam vitam posse constare...
} 
A partir de ese planteamiento fuerte de inicio retórico y filosófico, desarrolla fray Luis, con dispositio retórica perfectamente medida, las dos imágenes que como en espejo reflejan a la Madre en la tierra: sus hijas y sus libros. Sus hijas («como en espejos puros resplandece en todas un rostro que es el de la madre santa, que se traspasa a sus hijas») son una sucesión de milagros, «que un milagro es que una mujer, y sola haya reducido a perfección una Orden en mujeres y en hombres; y otro la gran perfección a que los redujo; y otro, y tercero, el grandísimo crecimiento a que ha venido». Paso a paso desarrolla la explicación de esa sucesión de milagros, explicitando la «maravilla grandísima» que provocan y sacando a la luz la admiración por sus virtudes.

«Y no es menos clara ni menos milagrosa la segunda que dije, que son las escrituras y libros». La primera valoración es ya definitiva y valiente, al atribuirlos a la inspiración divina: «y no dudo sino que hablaba el Espíritu Santo en ella en muchos lugares, y que la regía la pluma y la mano, que así lo manifiesta la luz que pone en las cosas oscuras, y el fuego que enciende con sus palabras en el corazón que las lee».

Esta afirmación nos parece a nosotros un ejercicio de ponderación hiperbólica; pero afirmado en ese momento y por ese hombre no deja de ponernos ante una valoración valiente. No podemos olvidar que la discusión sobre la labor inspirada o no de los traductores de la Biblia, y en particular el cuestionamiento de la Vulgata, es un tema central de las acusaciones contra fray Luis en el proceso, y de las de mayor peso teológico y recorrido judicial. Afirmar con esa rotundidad la inspiración sagrada de los escritos de una flaca mujer sola e indocta es apostar fuerte ${ }^{41}$.

A propósito de este carácter «milagroso» de los libros, no se ha señalado nunca, que yo sepa, la anécdota que recoge su sobrino, fray Basilio Ponce de León, cuando escribe en los papeles para la beatificación de la santa lo siguiente:

También oý decir al P. e fr. Luis de León, mi tío, que el tiempo que se ocupó en rebolver los libros de la Santa Madre sentía en ellos mui grande fragançia de olor, como lo suelen sentir las religiosas descalças, el cual tienen por señal que entonces está con ellas la Santa Madre $^{42}$.

En los procesos de beatificación insiste en el milagro odorífero, el olor de santidad, la carmelita María de San José:

\footnotetext{
${ }^{41}$ Por eso creo que no hay razón para ver en ello una reducción del estatuto autorial de Teresa que plantea GARRIGa EsPino, Ana, «La retórica epistolar de santa Teresa de Jesús», en Jesús García Rojo, ed., Teresa de Jesús: V centenario de su nacimiento. Historia, literatura y pensamiento, Salamanca, Diputación de Salamanca, 2015, p. 151. La estrategia de legitimación de la escritura femenina pone en juego modelos editoriales, como los que analiza BARANDA, N., ob. cit. p. 75, y entre ellos este.

${ }^{42}$ «El P.e Mo fray Basilio de León de la orden de San Agustín dice en los informes de Salamanca», TeresA DE Jesús, Correspondencia y otros papeles de Santa Teresa de Jesús, Madrid, BNE, MS 12763, ff 249-251.
} 
Preguntada si sabe que la dicha madre Teresa de Jesús haya muerto, y dónde, y cuándo, y si en su muerte haya habido algunas cosas notables, dijo:

\section{$(\ldots)$}

Este mismo olor ha oído decir a personas de mucho crédito, como son Ana de San Bartolomé, compañera de la dicha Madre, y otras religiosas, que muy de ordinario a deshora lo huelen en sus conventos. Y el padre fray Luis de León que escribía su vida dijo a esta testigo, que sentía algunas veces cuando escribía el mismo olor que en las reliquias. Y de dónde procede este olor las mismas personas dirán lo que entienden, aunque esta testigo lo tiene por misterio, y esto responde y lo que sabe ${ }^{43}$.

El carácter inspirado de los libros salta a la iconografía teresiana, que pasa de ser representada con la vera effigies (ver arriba nota 32) a reproducir la imagen del Espíritu Santo en forma de paloma sobre el bufete de escritura de la madre, asumiendo así el carácter inspirado de su escritura, que proclamaba ya fray Luis de León. Así se refiere a ello Diego de Yepes unos años después:

Y no es menor maravilla que una muger a quien si la común condición de su estado, escluye de ser enseñadora de otros, la particular gracia y aliento del cielo hiziesse maestra de muchos, moviendo el Espíritu Santo su pluma (como piadosamente creemos y se experimenta por los efectos) para que sin estudio humano (porque todo su saber era divino) escriviesse libros llenos de celestial dotrina ${ }^{44}$.

Junto con esta reivindicación valiente de la inspiración espiritual y milagrosa de los libros de la madre, fray Luis lleva a cabo la valoración de su estilo de escritura, que se ajusta al canon retórico clásico con el que ha valorado su misma prosa en la dedicatoria del Libro III de De los nombres de Cristo; esa valoración reside en la unión retórica de lo que se dice, la res («en la alteza de las cosas que trata») y en la forma de decirlo, las verba, organizadas por principios de la elocutio ( y en la delicadeza y claridad... y en la forma del decir y en la pureza y facilidad del estilo y en la gracia y buena compostura de las palabras»): la claridad, la pureza la buena compostura son los principios retóricos clásicos de la perspicuitas, latinitas y ornatus. Pero añade un matiz definitorio del estilo teresiano que marca con precisión la novedad de esa aplicación del sermo humilis agustiniano: «y una elegancia desafeitada que deleita en extremo». La elegancia desafeitada es un oxímoron expresivo donde «elegancia» vale lo que en el clásico de Lorenzo Valla (Elegantiae linguae latinae, el texto fundacional del humanismo) la cualidad artística definida como corrección, refinamiento y habilidad en la elección de las palabras; algo que no se compadece bien con ese adjetivo «desafeitada», que

\footnotetext{
${ }^{43}$ Procesos de beatificación y canonización de Santa Teresa de Jesús, ed. Silverio de Santa Teresa, OCD, Burgos, Monte Carmelo 1934, vol. 2, pp. 323-323.

${ }^{44}$ Diego de Yepes, «A nuestro Santíssimo y Beatíssimo Padre y Señor Nuestro Paula Papa Quinto», Vida, virtudes y milagros de la bienaventurada virgen Teresa de Iesus..., En Çaragoça por Angelo Tananno, 1606, s.p. Véase BALSINDE, I. y J. PoRTús, «El retrato del escritor en el libro español del siglo XVII», Reales Sitios 131 (1997), pp. 41-57.
} 
señala lo que no se ha compuesto con orden y artificio. Solo así, a través del oxímoron, puede abarcarse un estilo que se sale de la norma y que con justicia ha dado en definirse como «concertado desconcierto» ${ }^{45}$; en ella se sustenta el delectare horaciano que fray Luis pondera («que deleita en extremo»).

Que el maestro de la prosa renacentista, que ha proclamado con orgullo la solidez de su estilo para pocos («que el bien hablar no es común, sino negocio de particular juicio»), la atención y el cuidado en la selección y en la composición («que de las palabras que todos hablan, elige las que convienen, y mira el sonido dellas, y aun cuenta a veces las letras, y las pesa y las mide, y las compone...»), y ha defendido con orgullo su mérito personal («es nuevo y camino no usado por los que escriben en esta lengua poner en ella número, levantándola del descaimiento ordinario. El cual camino quise yo abrir...» $)^{46}$, que este príncipe de la prosa renacentista valore el estilo de la Madre en esos términos no deja de ser llamativo. Es una nueva retórica que levanta admiración por su fuerza expresiva y su eficacia ( $Y$ ansí, siempre que los leo, me admiro de nuevo»), que solamente se explica por inspiración divina.

La inspiración como base del estilo de Teresa, apreciado por fray Luis se sostiene, además, por las propias consideraciones de la madre, cuando trata de definir su manera de escritura:

porque cuando el Señor da espíritu, pónese con facilidad y mejor: parece como quien tiene un dechado delante, que está sacando aquella labor; mas si el espíritu falta, no hay más concertar este lenguaje que si fuese algarabía, a manera de decir, (...) Y así me parece es grandísima ventaja, cuando lo escribo, estar en ello, porque veo claro no soy yo quien lo dice, que ni lo ordeno con el entendimiento ni sé después cómo lo acerté a $\operatorname{decir}^{47}$.

Este modo de hablar del estilo de Teresa tiene su correlato en la definición de la poesía inspirada que pone fray Luis en boca de Marcelo en su diálogo De los nombres de Cristo:

sin duda la inspiró Dios en los ánimos de los hombres para con el movimiento y espíritu della, levantarlos al cielo, de donde ella procede; porque poesía no es sino una comunicación del aliento celestial y divino; y así, en los profetas cuasi todos, así los que fueron movidos verdaderamente por Dios como los que, incitados por otras causas sobrehumanas, hablaron, el mismo Espíritu que los despertaba y levantaba a ver lo que los otros hombres no vían, les ordenaba, y componía, y como metrificaba en la boca las palabras con número y consonancia debida, para que hablasen por más subida manera

\footnotetext{
${ }^{45}$ GARCÍA DE LA ConCHA, V., ob. cit., p. 184.

${ }^{46}$ Referencias todas de la conocida «Dedicatoria» del Libro tercero de De los nombres de Cristo, ed, cit., p. 333.

${ }^{47}$ Teresa de Jesús, Libro de la vida, 14, 9, ed. cit., p. 99.
} 
que las otras gentes hablaban, y para que el estilo del decir se asemejase al sentir, y las palabras y las cosas fuesen conformes ${ }^{48}$.

Incluso sus defectos, anacolutos, rupturas del hilo argumentativo... están tan diestramente ejecutados, con tal gracia «que ese mismo vicio le acarrea hermosura y es el lunar del refrán» ${ }^{49}$. Fray Luis aprecia ese estilo desconcertado teresiano, justamente lo contrario del propio estilo luisiano, que él mismo caracteriza por su «concierto». Frente al concierto, el desconcierto, pero con una eficacia (la utilitas retórica) que proporciona «grandes provechos que hallan los que leen estos libros... Que si entendieran bien castellano, vieran que el de la Madre es la misma elegancia». Una elegancia desafeitada de la que quizá no haya que excluir cierta atención y cuidado, como el que explicó con brillantez García de la Concha a propósito de la segunda redacción del Camino de perfección ${ }^{50}$, o el que podemos intuir en algunos comentarios al paso en las cartas, como cuando escribe al P. García de Toledo a principios de junio de 1562, protestando, no sin cierta coquetería estilística a modo de captatio benevolentiae, que no le ha dado tiempo a corregir lo escrito:

Yo he hecho lo que vuestra merced me mandó en alargarme a condición de que vuestra merced haga lo que me prometió en romper lo que mal le pareciere. No había acabado de leerlo después de escrito, cuando vuestra merced envía por él. Puede que vayan algunas cosas mal declaradas y otras puestas dos veces; porque ha sido tan poco el tiempo que he tenido que no podía tornar a ver lo que escribía ${ }^{51}$.

Tras la valoración estilística, debemos destacar en este encuentro en el libro entre los dos autores, una propuesta hermenéutica de lectura, por el cual la mano de la escritora pone luz en las cosas oscuras y enciende fuego con sus palabras en el corazón del que las lee, «quitándole de los ojos y del sentido todas las dificultades que hay». Leer es abrir un proceso de conocimiento y de perfección, incendiarse el lector en las mismas pasiones que sintió el escritor y aspirar a alcanzar lo que él (ella, en este caso) ya ha alcanzado («tan ansiosa del bien, que vuela luego a él con el deseo que hierve». El lector reescribe el libro en su lectura:

\footnotetext{
${ }^{48}$ LEÓN, fr. L. de, De los nombres de Cristo, libro I, «Monte», ed. cit., p. 110.

${ }^{49}$ Quizá, como explica Correas en su Vocabulario de refranes, «El lunar sobre los dientes, señor de sus parientes»; y glosa: «Manera de alabar el lunar que está sobre la boca, adonde parece mejor á la dama que los de otra parte del rostro, y un cantarcillo hay que lo alaba, junto á la boca. Señor de sus parientes, dice que es señor y rey de los otros lunares, y que la que le tiene es señora de sus parientes, esto es, estimada y tenida por hermosa de todos». U otros que recoge la misma colección: «La mujer lunarosa, de suyo se es hermosa».

${ }^{50}$ GARCía de la Concha, ob. cit., pp. 95-97.

51 Teresa De Jesús, Carta al P. García de Toledo, en Toledo, Ávila, principios de junio de 1562, en Obras completas, ed. cit., p. 736. «Tenía clara conciencia de lo que era buena o mala escritura», GARcía DE LA Concha, ob. cit. 2015, p. 22.
} 
Que dejados aparte otros muchos y grandes provechos que hallan los que leen estos libros, dos son, a mi parecer, los que con más eficacia se hacen. Uno, facilitar en el ánimo de los lectores el camino de la virtud; y otro, encenderlos en el amor de ella y de Dios.

Y esos mismos efectos de la reescritura del libro que es la lectura, experimenta fray Luis, convertido en lector, y en lector frecuente, como hemos visto, de la Madre. La lección de estos libros, dice, mejora y hace espirituales perfectos. Es, de nuevo lo recuerdo, la misma experiencia del pasaje del Tolle et lege agustiniano, cuya lectura en Las confesiones $(8,12)$ había provocado en Teresa efectos catárticos:

Como comencé a leer las Confesiones, paréceme me veía yo allí. Comencé a encomendarme mucho a este glorioso Santo. Cuando llegué a su conversión y leí cómo oyó aquella voz en el huerto, no me parece sino que el Señor me la dio a mí, según sintió mi corazón. Estuve por gran rato que toda me deshacía en lágrimas, y entre mí misma con gran aflicción y fatiga ${ }^{52}$.

El efecto de la lectura en el lector, que fray Luis de León destaca como uno de los milagros de la escritura («y ansí, siempre que los leo me admiro de nuevo» es el que se hace valer en los procesos de beatificación. En ellos, fray Basilio Ponce de León, el sobrino de fray Luis declara que:

y yo, con no ser nada tierno de corazón, siempre que los tomo en las manos para leerlos, me siento tocado con mil buenos afectos y con deseos mui afectuosos de darme de veras al camino de la virtud, y así siento muchos probechos en mi alma con su lección ${ }^{53}$.

Convertido en lector especializado, fray Luis actúa además de como crítico literario, como crítico textual, como auténtico filólogo. Lo que el Consejo Real encomienda a fray Luis fue trasladar a limpio los manuscritos para generar el original a partir del cual se había de hacer la impresión. Pero él mismo nos advierte de que no se ha limitado a cumplir lo que el Consejo Real le encomendó, «verlos y examinarlos». No. Fray Luis confiesa haberse tomado con ellos un «trabajo no pequeño», asumiendo el papel de editor, y actuando como un auténtico filólogo, cotejando los testimonios, «que estuvieron en mi poder muchos días». Cotejar es precisamente lo que hace el editor, que enfrenta los diversos testimonios para establecer las variantes, con voluntad de depurar el texto y que salga limpio, lo más cercano posible a la voluntad del escritor, sin errores, o sea, en palabras de fray Luis, «reducirlos a su propia pureza, en la misma manera en que los dejó escritos de su mano la Madre, sin mudarlos ni en palabras ni en cosas, de que se habían apartado mucho los traslados que andaban $»^{54}$. Confirma esta

\footnotetext{
${ }^{52}$ Teresa de Jesús, Libro de la vida, 9, 8, ed. cit., p. 64. Sobre fray Luis como lector véase SAN José LERA, J., «Los libros de fray Luis de León», Revista Agustiniana, 146 (2007), pp. 333-356.

53 «El P.e Mo fray Basilio de León de la orden de San Agustín dice en los informes de Salamanca», TERESA DE JEsús, Correspondencia y otros papeles de Santa Teresa de Jesús, Madrid, BNE, MS 12763, f. 250.

${ }^{54}$ El recorrido por los manuscritos y ediciones de cada una de las obras de Teresa de Jesús que pudo tener fray Luis a su disposición para la labor editorial puede verse detallado en LAzCANO, R., ob. cit.
} 
tarea filológica lo declarado por la madre Ana de Jesús en los procesos de beatificación de la madre Teresa:

A la última pregunta, de si sé que los libros que andan impresos en su nombre son suyos, sé lo tan cierto como las demás cosas que aquí tengo dichas, así por habérselos visto escribir, como por algunos traslados que de ellos sacaba. Cuando venían a sus manos, decía: "Dios los perdone a mis confesores que dan lo que me mandan escribir, y ellos por quedarse con ello trasládanlo y truecan algunas palabras, que ésta y ésta no es mía", y luego las borraba y ponía entre renglones de su letra, lo que le habían mudado, y así los que se imprimieron y andan ahora impresos se sacaron de los originales de su propia letra, y yo con licencia y orden de los prelados los junté, que estaban en diferentes partes, para darlos al maestro fray Luis de León ${ }^{55}$.

Por otra parte, sabido es que en el proceso de impresión de un libro en el siglo XVI se incorporaban tantos errores como en la difusión manuscrita. Hay que pensar en cajistas a veces inexpertos leyendo los originales, a veces tortuosos y no limpios, y componiendo a mano letra a letra, línea a línea y página a página lo que se va mandar a los tórculos. Por eso también es necesario cotejar el original de imprenta con lo impreso. Entiendo que la lectura filológica de fray Luis es doble, por un lado, cotejando los testimonios o traslados manuscritos para llevar al editor un original de imprenta limpio; y por otro, cotejando que lo impreso se ajusta al original. Ciertamente, un trabajo no pequeño, como atenúa con la lítote fray Luis. «Ansí que yo los he restituido a su antigua pureza», concluye con orgullo de filólogo. Y esto es así, aunque fray Luis trabaja con los condicionamientos de la filología de su tiempo, que concede mucho peso al iudicium del editor para modificar algunos pasajes oscuros, o en el caso de fray Luis, glosar los comprometidos teológicamente ${ }^{56}$. No obstante esto, no pudo evitar la reacción de quienes vieron en su edición peligros contra la ortodoxia, y la denunciaron a la Inquisición.

En ese contexto, un nuevo escrito, sumamente interesante, viene a completar el encuentro de ambos en los libros y el papel de fray Luis en la defensa de los libros de la Madre Teresa de Jesús. Se trata de la Apología del Padre Maestro Fray Luis de León, Catedrático de escritura de la Universidad de Salamanca. Donde muestra la utilidad que se sigue a la Iglesia en que las obras de la Beata Madre Teresa de Jesús y otras semejantes anden impresas en la lengua vulgar ${ }^{57}$. El texto resulta igualmente muy interesante, porque da respuesta a la recepción de la primera edición de 1588, que levantó protestas, delaciones

\footnotetext{
${ }^{55}$ Ana de Jesús en Procesos de beatificación y canonización de Santa Teresa de Jesús, ed. Silverio de Santa Teresa, OCD, Burgos, Monte Carmelo 1934, vol. 2, pp. 484-485.

${ }^{56}$ ÁLVAREZ, ob. cit., 1984, p. 495.

${ }^{57}$ El opúsculo lo dio a la luz el Padre Carmelita fray TomÁs DE JEsús en el apartado «Quán conveniente sea que estos libros anden en lengua vulgar», de su Suma y compendio de los grados de oración...sacado de todos los libros y escritos que compuso la Beata Madre Teresa de Jesús... en Roma, Por Iacomo Mascardo, 1610 (edición anterior a la que se suele citar En Madrid, Por Luis Sánchez, 1615; la cita correctamente LAZCANO, R., art.cit, p. 97, n. 66), s. p. Cito de León, Obras completas castellanas, Madrid, BAC, 1991, vol. I, pp. 915-920.
} 
y la denuncia formal ante la Inquisición del dominico Alonso de la Fuente, el 12 de octubre de 1589:

A mis manos ha venido un libro que se intitula Los libros de la Madre Teresa de Jesús, impreso en Salamanca por Guillermo Foquel año pasado de 1588. Y habiéndole leído y considerado atentamente, hallo en él escrita la secta masiliana con ramarazos de otras sectas, especialmente de los herejes estáticos, alumbrados y dexados... El autor de dicho libro lo vende y encomienda por dotrina revelada de Dios e inspirada por el Espíritu Santo (...) es negocio fabuloso o prestigio de Satanás o invención de herejes ${ }^{58}$.

De forma que fray Luis pasa de ser editor a ser apologista obligado por las circunstancias. La Apología responde al mismo impulso que ha llevado a fray Luis a contestar a sus detractores en la Dedicatoria del Libro III de De los nombres de Cristo, en la segunda edición de la obra (1585), dejando así constancia de la recepción de la misma. Aquí igualmente, pues «algunos según he oído... han hablado menos bien que debían», por tres razones: porque enseñan oración de unión, porque tienen algunas cosas escuras para ser entendidas generalmente de todos, porque cuenta en ellos muchas revelaciones que tuvo.

Con la sistemática organización argumental que le es propia va desplegando sus argumentos de defensa, en primer lugar, sobre la oración de unión, alegando autoridades de la Sagrada Escritura (por donde consta «que hay oraciones de raptu o éxtasis») así como de doctores latinos (San Buenaventura, Ricardo de San Víctor, Juan Gerson) y romances (los Abecedarios de Osuna). En segundo lugar, sobre la «escuridad», defendiendo con argumento retórico y poético, la licitud de una obscuritas que deriva no de las palabras, sino de las cosas, que crea admiración y deseo de la experiencia. $Y$ en tercer lugar, de las revelaciones, donde se extiende por ser asunto más delicado, con un despliegue de argumentos de autoridades, de recursos de una retórica afectiva ( « Por qué se ha de encubrir lo que es bueno, lo que hace maravilla de Dios, lo que enciende en su reverencia y amor, lo que pone espuelas para toda santidad y virtud?»), pasando por la ironía («Engañada ha estado la Iglesia, que hasta agora ha escrito y querido que se lea lo que abre la puerta al demonio...») o la denuncia acre:

Porque ellos no las creen ¿qué? ¿Por eso se han de vedar a los otros? Presunción intolerable es hacerse señores de los juicios de todos. No las creen... Porque no lo experimentan en sí ¿no quieren que sea posible en los otros? (...) ¿No las creen? Libres son, no las crean; señores son de su juicio: nadie les hace fuerza, sean sospechosos, sean resabidos, sean cuantos quisieren incrédulos. Mas yo, sí las creo...

La conclusión es firme y poderosa:

\footnotetext{
${ }^{58}$ LLAMAS MARTínEZ, ob. cit., p. 396. Se ha señalado con acierto que esas referencias indefinidas, "gentes", algunos", con que se recogen las críticas a la escritura femenina constituyen estrategias para la descalificación de los argumentos opuestos (Baranda, N., ob. cit., p. 75, n. 25); pero estrategia retórica, porque las denuncias de los escritos de Teresa y de la edición y defensa de fray Luis no son anónimas.
} 
Y asi concluyo diciendo que tengo por sin duda que trae el demonio engañados a los que destos libros no hablan con la reverencia que deben; y que sin duda les menea la lengua para, si pudiese por su medio, estorbar el provecho que hacen. $Y$ veese claramente por esto: si se movieran con espíritu de Dios, primero y ante todas cosas, condenaran los libros de Celestina, los de caballería y otras mil prosas, obras llenas de vanidades y lascivias, con que cada momento se emponzoñan las almas. Mas como no es Dios quien los mueve, callan esto que corrompe la Cristiandad y costumbres y hablan de los que las ordena y recoge y lleva a Dios con eficacia grandísima.

El repudio de las ficciones profanas es argumento humanista y moralista habitual, como es bien sabido, para defender el provecho de los buenos libros frente a los dañosos, que fray Luis repite, por ejemplo, en la dedicatoria a Pedro Portocarrero del libro I de De los nombres de Cristo o en La perfecta casada IV: «...las absuelvan de otros mil importunos y memorables trabajos con que atormentan sus cuerpos y rostros, y que las excusen y libren del leer en los libros de caballerías, y del traer el soneto y la canción en el seno...» (p. 111). Pero donde más cerca está de acordarse de los escritos de Teresa de Jesús es en el nombre «Monte» del libro I de De los nombres de Cristo, cuando afirma:

[los libros dañosos] corrompen también, lo que es mayor mal, las santas costumbres; porque los vicios y las torpezas, disimuladas y enmeladas con el sonido dulce y artificioso del verso, recíbense en los oídos con mejor gana, y dellos pasan al ánimo, que de suyo no es bueno, y lánzanse en él poderosísimamente, y hechas señoras dél, y desterrando de allí todo buen sentido y respeto, corrómpenlo, y muchas veces sin que el mismo que es corrompido lo sienta. $\mathrm{Y}$ es -iba a decir donaire, y no es donaire sino vituperable inconsideración- que las madres, celosas del bien de sus hijas, les vedan las pláticas de algunas otras mujeres, y no les vedan los versos y los cantarcillos de argumentos livianos, los cuales hablan con ellas a todas horas, y sin recatarse dellos, antes aprendiéndolos y cantándolos, las atraen a sí y las persuaden secretamente, y derramándoles su ponzoña poco a poco por los pechos, las inficionan y pierden (ed. cit., p. 111).

En conclusión, la condición histórico-literaria de los textos teresianos no puede ser estudiada sin tener en cuenta el papel intermediario que, en su configuración, en su transmisión y en su valoración juega la labor filológica de fray Luis de León. El encuentro en el libro del agustino con la Madre resulta esencial y visibiliza el poder sobre la escritura que se ejerce por parte del teólogo salmanticense, a quien se otorga esa capacidad de control, en función de su autoridad, por parte de las responsables carmelitas. Fray Luis tuvo la autoridad y supo qué hacer con ella (lo que responde a la pregunta que se hace Cristina Morales en su relato de 2020: «¿Qué hacer con la autoridad cuando se la tiene?», p. 199). El estatus social y cultural del agustino actúa de aval de los escritos de la madre, y por eso el ataque contra los unos, pasa por el desprestigio del otro, cuestionando, precisamente, su autoridad. Es el sentido de esa despectiva expresión «alias vir doctus» (algo así como «el tal doctor»), que se percibe en el apelativo con que Alonso de la Fuente moteja a fray Luis: 
El Padre Maestro León, alias vir doctus, no entendió o no quiso entender lo questá claro en esta escriptura (...) Y en esto se ve claramente que no supo cosa alguna desta doctrina, ni de los misterios della ${ }^{59}$.

El editor filólogo actúa como verdadero «productor de escritura», contribuyendo decisivamente a la institucionalización literaria del objeto con el que trabaja ${ }^{60}$. Su papel es esencial para permitir que Teresa escape de su mundo, de su época y nos alcance en este tercer milenio (parafraseo a Kristeva, op. cit. p. 30). Y lo hace superando con mucho esos modelos editoriales que sitúan en el paratetexto inicial de la dedicatoria elementos estratégicos de legitimación. Ciertamente es el hombre docto el que autoriza la escritura femenina; pero lo hace desde una sincera admiración que va más allá de la «jerarquía de género» ${ }^{61}$.

«De la lección, dicen, nace el deseo» afirma fray Luis en la Apología. Y la lectura de los libros de la Madre Teresa mueve al deseo de imitarla, como hemos visto en los testimonios del propio agustino y en su sobrino fray Basilio Ponce de León. Pero además de la intención espiritual que muestra como aficionado (en el sentido etimológico del término, 'enamorado', el que ha sido conquistado en su voluntad por la hermosura de algo), la admirable defensa de la lectura que como humanista, como teólogo y como filólogo hace el agustino surte efectos en varios terrenos. Invitación a la lectura que es deleite estético y alimento espiritual del alma; lectura que es resonancia impresa de la misma dimensión estética y espiritual de la Madre, reflejo de su alma, armónicos de su naturaleza que caminaba a la santidad. Y ese camino también lo quiso abrir la valiente, la ardorosa, la sabia defensa de lectura de unos libros elevados a autoridad casi bíblica $^{62}$.

Fray Luis, en su encuentro en el libro con Teresa de Jesús, canoniza su obra de la que se hacen enseguida numerosas ediciones en España y en Europa, teniendo

\footnotetext{
${ }_{59}$ Alonso de la Fuente, «Cuarto memorial al Consejo de la Inquisición», en LLAMAS MARTínEz, op. cit., pp. 415-416.

${ }^{60}$ Petrucci, A., «Pouvoir de l'écriture pouvoir sur l'écriture dans la Renaissance italienne», Annales. Economies, sociétés, civilisations, $43^{\circledR}$ année, N. 4, 1988., p. 823. Esa capacidad institucionalizadora ha sido identificada para explicar «el frágil estatuto literario que le fue otorgada a las cartas teresianas» al no aparecer en la edición preparada por fray Luis, GARRIGA, A. «La retórica epistolar de santa Teresa de Jesús», en García Rojo, ed. cit., p. 151.

${ }^{61}$ BARANDA, N., ob. cit., p. 76. Aunque la misma autora afirma: «La edición de las obras de Teresa era excepcional porque se trataba de una mujer coetánea y no de la antigüedad ni de una santa; alcanzaba el estatus de escritora, es decir, de voz pública con magisterio reconocido, y no proyectaba por ello una imagen negativa como mujer, sino a la inversa», BARANDA LETURIO, N. «Teresa de Jesús y el incierto camino de la escritura femenina hispana. Antecedentes y consecuencias del modelo», en Jesús García Rojo, ed., Teresa de Jesús: V centenario de su nacimiento. Historia, literatura y pensamiento, Salamanca, Diputación de Salamanca, 2015, p. 185.
}

${ }^{62}$ Thompson, C., ob. cit., p. 296. 
cerca la princeps salmantina- ${ }^{63}$, consagra a la escritora y la autoriza con la autoridad del teólogo prestigioso desde su cátedra de Biblia, del humanista a quien se reconoce como maestro del idioma y conocedor del mundo clásico y cristiano, de la literatura profana y de la espiritual. La Carta y la Apología constituyeron dos pilares básicos para la difusión y apreciación de la obra de aquella mujer de estilo diminutivo y alma grande y por eso podría considerarse tanto base para su institucionalización en la historia literaria como también cimiento de la construcción de su santidad ${ }^{64}$. Ambos, junto con la posible coincidencia en el Cantar de los Cantares, visibilizan los encuentros de fray Luis de León y Teresa de Jesús en los libros. Fructífero encuentro el de los dos gigantes de la espiritualidad, aun cuando no se produjo en el espacio geográfico que compartieron, sino en ese otro espacio compartido del libro y de la lectura. Como escritor y poeta, como humanista filólogo y como teólogo, fray Luis de León consagró a Teresa de Jesús.

\section{Bibliografía}

Alabrús, R., y García CárCel, R., Teresa de Jesús. La construcción de la santidad femenina, Madrid, Cátedra, 2015.

Álvarez, T., «Fray Luis de León y Santa Teresa. El profesor salmantino ante la monja escritora», en Santa Teresa y la literatura mística hispánica, ED-6, Madrid, 1984, pp. 493-502.

, «Santa Teresa de Jesús. Primera onda difusora de sus escritos», en Teresa de Jesús. La prueba de mi verdad (Catálogo de la exposición), Madrid, Biblioteca Nacional de España, Acción Cultural Española, 2015, pp. 149-166.

Álvarez Turienzo, S. (ed.), Escritos sobre Fray Luis de León: el teólogo y maestro de espiritualidad, Salamanca, Ediciones de la Diputación de Salamanca, 1993.

Azorín, Los dos luises y otros ensayos, Madrid, Austral, 1944.

, «Teresa de Jesús (1515-1582», Los clásicos redivivos, Madrid, Austral, 1945, pp. 39-43.

, «Ventana a Santa Teresa», Revista de Espiritualidad, 87-89 (1963), p. 399-407.

BALSINDE, I. y PORTús, J., «El retrato del escritor en el libro español del siglo XVII», Reales Sitios 131 (1997), pp. 41-57.

BARANDA LETURIO, N., «Nombres aniquilados: publicaciones femeninas y lectores», Criticón, 125 (2015), pp. 65-77. https://cvc.cervantes.es/literatura/criticon/ PDF/125/125_065.pdf (recuperado 29/07/2020).

\footnotetext{
${ }^{63}$ Ver Sebastián Mediavilla F., «Historia del texto», en Teresa de Jesús, Libro de la vida, ed.cit., p. 483-487. Álvarez, T., ob. cit., 2015, p. 159 y ss. BouzA. F., «Teresa de Jesús, Olivares y la edición plantiniana de las obras de la s. Madre o de la Palma (1630)», Avisos. Noticias de la Real Biblioteca, XXI, 76 (mayo-agosto, 2015), pp. 1-4.

${ }^{64}$ Alabrús, R., y R. GARCía CÁRcel, Teresa de Jesús. La construcción de la santidad femenina, Madrid, Cátedra, 2015.
} 
, «Teresa de Jesús y el incierto camino de la escritura femenina hispana. Antecedentes y consecuencias del modelo», en Jesús García Rojo, ed., Teresa de Jesús: $V$ centenario de su nacimiento. Historia, literatura y pensamiento, Salamanca, Diputación de Salamanca, 2015, pp. 169-199.

BouzA, F., «Teresa de Jesús, Olivares y la edición plantiniana de las obras de la s. Madre o de la Palma (1630)», Avisos. Noticias de la Real Biblioteca, XXI, 76 (mayo-agosto, 2015), pp. 1-4. https://avisos.realbiblioteca.es/index.php/Avisos/article/ view/509 (recuperado 29/07/2020).

CHECA, F., «Santa Teresa de Jesús y las imágenes artísticas», en Teresa de Jesús. La prueba de mi verdad (Catálogo de la exposición), Madrid, BNE, AC/E, 2015, pp. 103129.

EgIDO, T., «Santa Teresa y sus cartas, historia de los sentimientos», Hispania Sacra, LXVII,136, (2015), pp. 401-428.

GarCía De La Concha, V., El arte literario de Santa Teresa, Barcelona: Ariel, 1978. , «De los nombres de Cristo, comentario al Cantar de los Cantares», en García de la Concha, V. y San José Lera, J., Fray Luis de León. Historia, humanismo y letras, Salamanca, Ediciones Universidad Salamanca, 1998, pp. 381-394.

, «Teresa de Jesús», en Teresa de Jesús. La prueba de mi verdad (Catálogo de la exposición), Madrid, BNE, AC/E, 2015, pp. 3-26.

Garriga Espino, A., «La retórica epistolar de santa Teresa de Jesús», en Jesús García Rojo, ed., Teresa de Jesús: $V$ centenario de su nacimiento. Historia, literatura y pensamiento, Salamanca, Diputación de Salamanca, 2015, pp. 147-161.

, Teresa de Jesús en el laberinto de sus cartas, Madrid, Tesis doctoral de la UAM, 2017. https://repositorio.uam.es/handle/10486/681478 (recuperado 29/07/2020).

Herrera, T. de, Historia del Convento de San Agustín de Salamanca, Madrid, Gregorio Rodríguez, 1652.

Jesús, fray Tomás de, Suma y compendio de los grados de oración por donde sube un alma a la perfeción de la Contemplación, sacado de todos los libros y escritos que compuso la Beata Madre Teresa de Jesús... en Roma, Por Iacomo Mascardo, 1610.

Kristeva, J., Teresa, Amor mío, Barcelona, Paso de Barca, 2015.

LAZCANO, R., «Fray Luis de León, editor y biógrafo de Teresa de Jesús (1515-1582)», Analecta Augustiniana 78 (2015), pp. 78-115.

León, Fray Luis de, Obras completas castellanas, ed. Félix García, O.S.A., Madrid, Biblioteca de Autores Cristianos, 1991.

Exposición del Libro de Job, ed. Javier San José Lera, Salamanca, Ediciones Universidad Salamanca, 1992.

, La perfecta casada, ed. Javier San José Lera, Madrid, Espasa Calpe, col. Austral, 1992.

- De los nombres de Cristo, ed. Javier San José Lera, Barcelona, Galaxia GutenbergCírculo de Lectores, 2008. 
Llamas Martínez, E., OCD., Santa Teresa de Jesús y la Inquisición española, Madrid, CSIC, 1972.

Lopetegui, L., «Censura de la Orden de la Vida de Santa Teresa de Jesús, por Francisco de Ribera, S.I.», Manresa, vol. 16, nº 60 (1944), pp. 261-274.

Mancho Duque, M ${ }^{\mathrm{a}}$ J., «Claves de la escritura teresiana», Salamanca. Revista de Estudios 59 (2014), 103-122.

Mancho Duque, Ma J. y Prieto, J. M. (eds.), Fray Luis de León, De la vida, muerte, virtudes y milagros de la Santa Madre Teresa de Jesús, Salamanca, Ediciones Universidad, 1991.

Manrique, Á., Vida de la Venerable Madre Ana de Jesús, Bruxellas, En casa de Lucas de Meerbeck, 1632.

Maroto, Daniel de Pablo, «Meditaciones sobre los Cantares», en Alberto Barrientos (dir.), Introducción a la obra de santa Teresa, Madrid, Editorial de Espiritualidad, 1978, pp. 383-391.

Márquez Villanueva, F. «La vocación literaria de Santa Teresa», Nueva Revista de Filología Hispánica, 32.2 (1983), pp. 355-379.

Menéndez PIDAL, R., «El estilo de Santa Teresa», La lengua de Cristóbal Colón, Madrid, Austral, 1978, 6a ed. pp. 119-142.

Morales, C., Introducción a Teresa de Jesús, Barcelona, Anagrama, 2020.

NAKLÁdAlovÁ, Y., La lectura docta en la primera Edad Moderna (1450-1650), Madrid, Abada Editores, 2013.

Petrucci, A. «Pouvoir de l'écriture pouvoir sur l'écriture dans la Renaissance italienne», Annales. Economies, sociétés, civilisations, 43e année, N. 4, (1988), pp. 823-847. https://www.persee.fr/doc/ahess 0395-2649 1988 num $43 \quad 4 \quad 283525$ (recuperado 29/07/ 2020).

Pinilla Martín, $\mathrm{M}^{\mathrm{a}}$ J., «Tipos y temas en la iconografía teresiana, Aspectos relativos a su configuración y desarrollo», en Jesús García Rojo, ed., Teresa de Jesús: $V$ centenario de su nacimiento. Historia, literatura y pensamiento, Salamanca, Diputación de Salamanca, 2015, pp. 17-30.

SAN José LeRA, J., «Un recurso clásico en la prosa de fray Luis de León: las parejas de sinónimos en la Exposición del libro de Job», en Manuel García Martín, ed., Estado actual de los estudios sobre el Siglo de Oro: actas del II Congreso Internacional de Hispanistas del Siglo de Oro Salamanca, Ediciones Universidad Salamanca, 1993, Vol. 2, pp. 913-922.

, «Los libros de fray Luis de León», Revista Agustiniana, 144 (2007), pp. 333-356.

SANTA ANA, B.-I., Vida de la madre Ana de Jesús, Burgos, Imprenta de San José, 1901.

TERESA DE Jesús, Santa, Tratado que escrivio la madre Teresa de Jesus a las hermanas religiosas dela orden de nuestra senhora del Carmen del monesterio del senhor sanct Joseph de Avila de donde a la sazon era priora y fundadora, Évora, viuda de Andrés Burgos, 1583. 
- Los libros de la Madre Teresa de Jesús, fundadora de los monesterios de monjas y frayles Carmelitas descalços de la primera regla. Salamanca, Por Guillelmo Foquel, 1588. http://bibliotecadigital.jcyl.es/es/ consulta/resultados_ocr.cmd?autor_numcontrol=\&materia_ numcontrol=\&id=1572\&tipoResultados=BIB\&posicion $=3 \&$ forma $=$ ficha (recuperado 29/07/2020).

, Correspondencia y otros papeles de Santa Teresa de Jesús, MS 12763, Madrid, Biblioteca Nacional de España, letra del s. XVII.

- Procesos de beatificación y canonización de Santa Teresa de Jesús, ed. Silverio de Santa Teresa, OCD, Burgos, Monte Carmelo 1934, 3, vols.

, Obras completas, Madrid, Aguilar, 11ª ed., 1990.

Libro de la vida, ed. Fidel Sebastián Mediavilla, Madrid, Real Academia Española, 2014.

Thompson, C., «“Una elegancia desafeitada”. Fray Luis de León y Santa Teresa», en Gaylord, M. M. y Márquez Villanueva, F. (eds.), San Juan de la Cruz and Fray Luis de León, Juan de la Cuesta, Newark, Delaware, 1996, pp. 289-298.

Torres, C. (ed.), Ana de Jesús, Cartas (1590-1621). Religiosidad y vida cotidiana en la clausura femenina del Siglo de Oro, Salamanca, Ediciones Universidad, 1995.

VIDal, M., OSA. Augustinos de Salamanca. Historia del observantíssimo Convento de S. Agustín N. P. de dicha ciudad, Salamanca, Salamanca, Eugenio García de Honorato y San Miguel, impresor, 1751-58, 2 vols.

Viñas Román, T., Fray Luis de León. El hombre, el teólogo, el poeta, el amigo, el místico, Salamanca, Diputación de Salamanca, 2018.

YEPES, Diego de, Breve relación de algunas cosas notables de la santa madre Teresa de Jesús, escrita y enviada por el Reverendíssimo Obispo de Tarazona, Fray Diego de Yepes, siendo visitador de su Orden, al doctíssimo Padre Fray Luis de León Catedrático de Escritura de la Universidad de Salamanca, en Libros de la B. Madre Teresa de Jesus fundadora de los monasterios de monjas y frayles carmelitas descalzos de la primitiva regla que contienen un tratado de su vida, Napoli, Por Constantin Vidal, 1604.

Vida, virtudes y milagros de la bienaventurada virgen Teresa de Iesus..., En Çaragoça por Angelo Tananno, 1606.

Zozaya Montes, L., «Algunas aclaraciones sobre Guillermo Foquel, un impresor del siglo XVI», Torre de los Lujanes $\mathrm{N}^{\circ} 43$ (2001), pp. 189-203. 